\title{
Effect of Estradiol-17 $\beta$ and Progesterone in Co-Culture with Uterine Epithelium Cells on Rat Embryo Development
}

\author{
Hirotada Tsujii \\ Department of Agricultural Biotechnology, Faculty of Agriculture, Shinshu University, \\ Minamiminowa-mura, Kamiina-gun, Nagano-ken 399-4511, Japan
}

\begin{abstract}
This experiment was designed to evaluate the ability of Estradiol-17B $\left(E_{2}\right)$ and progesterone $\left(P_{4}\right)$ to promote development of rat blastocysts. Eight-cell rat embryos were co-cultured for 5 days with rat uterine epithelium (UE) cells with inclusion of $E_{2}$ and/or $P_{4}$. Embryos were collected from mature Wistar-Imamichi rats. UE cells were recovered from the same washed with modified TCM199 (m 199FCS) and placed in 4-well Multi-dishes. UE cells of monolayers were developed to $70-80 \%$ confluence prior to initiation of the embryo culture. Embryos were recovered, selected and randomly placed in one of the four steroid hormone dose concentration media. They were evaluated every $24 h$ to determine their stage of development. More $(p<0.05)$ embryos were developed to both hatched and posthatched blastocysts in $E_{2}$ with a concentration of $3.5 \times$ $10^{-5}, 10^{-4} M$ and $P_{4}$ with a concentration of $3.5 \times 10^{-6}$, $10^{-5}, 10^{-4} \mathrm{M}$. The combination of $E_{2}\left(3.5 \times 10^{-5} \mathrm{M}\right)$ and $P_{4}\left(3.5 \times 10^{-6}, 10^{-5}, 10^{-4} \mathrm{M}\right)$ also improved $(p<0.05)$ both hatched and post-hatched blastocysts. These finding showed that the presence of ovarian steroid hormones in a primary culture of UE cells promotes in vitro development of post-blastocysts in rat embryos.
\end{abstract}

Key words: Estradiol-17ß, Progesterone, Co-culture, Rat embryo, Uterine epithelium cell.

The culture of embryos in vitro removes the embryo from the maternal environment where it is bathed in an ever-changing natural fluid containing a range of proteins and ions specific to reproductive fluid $[1,2]$. In a recent study [3] it was observed that 1-cell rat embryos developed to the blastocyst stage when co-cultured with oviductal cells, so that the use of oviductal cells in embryo co-culture systems has attracted attention in understanding the mechanisms by which helper cells

Received: August 28, 1997

Accepted: November 26, 1997 interact with embryos to enhance in vitro development. Development of the preimplantation mammalian embryo in vitro occurs in a complex luminal environment whose volume and composition are under the control of the ovarian hormones progesterone $\left(\mathrm{P}_{4}\right)$ and estradiol-17 $\beta$ $\left(E_{2}\right)[4,5]$. It has been proposed that interaction between uterine epithelial (UE) cells and various regulatory agents (hormones and growth factors) effect (induce, stimulate or repress) structural and functional changes at the apical surface of the UE cell that allow nidation. Nevertheless, the UE cellular mechanisms and the effects on embryos involved in these $P_{4}$ : $E_{2}$ regulated processes are not clearly understood.

Receptivity is therefore not accomplished by a simple "turn-on" of protein or glycoprotein synthesis [6,7], but rather regulatory complexes acting directly on the UE cell paracrine factors may coordinately and differentially vary molecular synthesis and traffic to the appropriate plasma membrane domain of the UE cell.

The object of this study was to evaluate the effect of ovarian hormones in co-culture with uterine epithelium cells on 8-cell rat embryo development.

\section{Materials and Methods}

Animals and Embryo collection: Adult virgin female rats of Wistar-Imamichi strain weighing from 200 to 240 $\mathrm{g}$ were used. They were maintained under controlled light conditions ( $12 \mathrm{~h}$ light: $12 \mathrm{~h}$ darkness: light on at 6:00 h) and allowed to take pelted diet and water freely. Vaginal smears were taken in the morning for assessment of proestrus and graded. They were mated with the same strain fertile males on the evening of proestrus. The day when spermatozoa were detected in the vaginal smear was considered day 1 of pregnancy. Eight-cell embryos were collected by flushing the oviduct with culture medium in the early morning of day 4 . 
Collection of uterine epithelial cells: The uteri were trimmed free of ligaments and slit lengthwise on the side of the mesosulphinx. Cells from the uterus were collected by lightly scraping the luminal surface with a scalpel and suspended in tissue culture medium in a 4well Multi-dish (Nunc, Denmark). The UE cells were cultured at $37.5^{\circ} \mathrm{C}$ in an atmosphere of $95 \%$ air: $5 \%$ $\mathrm{CO}_{2}$. UE cell monolayers were developed for 4 days to $70-80 \%$ confluence before starting the embryo culture.

Culture medium and culture: The basic culture medium was modified Krebs-Ringer-bicarbonate solution [8] containing $25 \mathrm{mM}$ lactate, $0.25 \mathrm{mM}$ pyruvate and supplemented with antibiotics and $1 \mathrm{mg} / \mathrm{ml}$ bovine serum albumin. Embryos were randomly assigned to each treatment group from the pooled embryos. All incubations were carried out at $37.5^{\circ} \mathrm{C}$ and in a humidified atmosphere of $5 \% \mathrm{CO}_{2}$ and $95 \%$ air. The medium was changed $48 \mathrm{~h}$ after starting the culture. For co-culture, TCM199 (Sigma, USA) was supplemented with sodium lactate $25 \mathrm{mM}$, sodium pyruvate $0.5 \mathrm{mM}$ and $10 \%$ fetal calf serum (modified 199; m199FCS). Penicillin (20 IU/ $\mathrm{ml})$ and streptomycin $(20 \mu \mathrm{g} / \mathrm{ml})$ were also added as antibiotics. According to the experimental design $P_{4}$ and $E_{2}$ (Sigma, USA) were added to the culture medium in different concentrations as follows:

Experiment 1: Only $\mathrm{P}_{4}$ in concentrations of $3.5 \times 10^{-6}$, $3 \times 10^{-5}$ and $3 \times 10^{-4} \mathrm{M}$.

Experiment 2: Only $\mathrm{E}_{2}$ in concentrations of $3.5 \times 10^{-6}$, $3 \times 10^{-5}$, and $3 \times 10^{-4} \mathrm{M}$.

Experiment 3: Co-culture with $\mathrm{P}_{4}$ and $\mathrm{E}_{2}$ in a combination. $P_{4}$ are $3.5 \times 10^{-6}, 10^{-5}$ and $10^{-4} \mathrm{M}$ and $E_{2} 3.5 \times$ 10-5 M.

Experiment 4: In conditioned medium, $\mathrm{P}_{4}$ and $\mathrm{E}_{2}$ were added in the same concentrations as in Experiment 3. For this experiment, UE monolayers were developed for 4 days to $70-80 \%$ confluence and the supernant were collect and used as conditioned medium.
All these doses of steroid hormone mentioned above cover the physiological range of concentrations.

Evaluation of embryo development and statistical analysis: Post-hatching embryos were recorded as achieving stage 1 when they displayed proliferating trophoectoderm cells and stage 2 when they showed outgrowth of trophoectoderm cells on the bottom of the culture vessel. Data were evaluated for statistically significant differences by $\chi^{2}$-test.

\section{Results}

Effects of the inclusion of $\mathrm{P}_{4}$ in co-culture on the development of rat embryos are shown in Table 1. There was no difference between the control and $\mathrm{P}_{4}$ treatment groups in terms of blastocyst development, but both hatched and stage 1 post-hatched blastocysts increased significantly $(p<0.05)$ compared with the control. No difference among the $\mathrm{P}_{4}$ doses was found, but the concentrations of $3.5 \times 10^{-6}$ and $3 \times 10^{-5} \mathrm{M}$ of $\mathrm{P}_{4}$ resulted in better post-hatched development.

Effects of the inclusion of $E_{2}$ in co-culture on the development of rat embryos are shown in Table 2. Like $P_{4}$, there was no difference between the control and $E_{2}$ treatment groups in terms of blastocysts. Here, hatched and post-hatched blastocyst development at both stages increased significantly $(p<0.05)$ with the $3.5 \times 10^{-5}$ and $3 \times 10^{-4} \mathrm{M}$ concentrations of $E_{2}$ compared with the control. Combined effects of $\mathrm{P}_{4}\left(3.5 \times 10^{-6}, 10^{-5}, 10^{-4} \mathrm{M}\right)$ and $E_{2}\left(3.5 \times 10^{-5} \mathrm{M}\right)$ on the development of rat embryos cultured in m199 FCS medium are shown in Table 3. Development remains similar up to the blastocyst stage but the hatched and post-hatched blastocyst developments in both stages increased significantly $(p<0.05)$ in all concentration groups other than the control.

Similarly, when the $\mathrm{P}_{4}$ concentration was to $3.5 \times$ $10^{-6}, 10^{-5}, 10^{-4} \mathrm{M}$ with $\mathrm{E}_{2}\left(3.5 \times 10^{-5} \mathrm{M}\right)$ in the conditioned

Table 1. Development of rat embryos in co-culture: effect of the inclusion of progesterone in the m199 FCS medium

\begin{tabular}{clcrcr}
\hline $\begin{array}{l}\text { Day of } \\
\text { culture }\end{array}$ & $\begin{array}{c}\text { Developmental } \\
\text { stage }\end{array}$ & 0 & \multicolumn{4}{c}{ Progesterone $(3.5 \times \mathrm{M})$} \\
\cline { 4 - 6 } & & \multicolumn{1}{c}{$10^{-6}$} & \multicolumn{1}{c}{$10^{-5}$} & \multicolumn{1}{c}{$10^{-4}$} \\
\hline 0 & Eight-cell & $323(\%)$ & $215(\%)$ & $210(\%)$ & $203(\%)$ \\
1 & Morula & $310(96.0)^{\mathrm{a}}$ & $207(96.3)^{\mathrm{a}}$ & $202(96.2)^{\mathrm{a}}$ & $194(95.6)^{\mathrm{a}}$ \\
2 & Blastocyst & $303(93.8)^{\mathrm{a}}$ & $203(94.4)^{\mathrm{a}}$ & $197(93.8)^{\mathrm{a}}$ & $190(93.6)^{\mathrm{a}}$ \\
3 & Hatched blastocyst & $61(18.9)^{\mathrm{a}}$ & $76(35.3)^{\mathrm{b}}$ & $71(33.8)^{\mathrm{b}}$ & $61(30.0)^{\mathrm{b}}$ \\
4 & Post-hatch stage 1 & $35(10.8)^{\mathrm{a}}$ & $65(30.2)^{\mathrm{b}}$ & $62(29.5)^{\mathrm{b}}$ & $56(27.6)^{\mathrm{b}}$ \\
5 & Post-hatch stage 2 & $33(10.2)^{\mathrm{a}}$ & $65(30.2)^{\mathrm{b}}$ & $61(29.0)^{\mathrm{b}}$ & $52(25.6)^{\mathrm{b}}$ \\
\hline
\end{tabular}

$a, b$ differ significantly from each other $(p<0.05)$. 
medium, results followed the same trend as in Tables 3 and 4. Development remains similar up to the blastocyst stage but the hatched and post-hatched blastocyst development of both types increased significantly $(p<0.05)$ in all combination groups other than the control.

\section{Discussion}

The addition of $\mathrm{P}_{4}$ and/or $\mathrm{E}_{2}$ has shown effects on hatched blastocysts and post-hatched blastocysts in co- culture with UE cells.

The secretions of UE support survival of both the sperm and the blastocysts $[9,10]$. The UE cells provide an apical surface, which permits embryo attachment [1113]. There was also observed a basal surface that presumably transduces a blastocyst signal, which initiates stromal cell differentiation [14-16]. The UE cell responses can be directed by alterations in the hormonal environment [17-20], and it is likely that expression of those components which are directly in-

Table 2. Development of rat embryos in co-culture: effect of the inclusion of estradiol-17 $\beta$ in $\mathrm{m} 199$ FCS medium

\begin{tabular}{|c|c|c|c|c|c|}
\hline \multirow{2}{*}{$\begin{array}{l}\text { Day of } \\
\text { culture }\end{array}$} & \multirow{2}{*}{$\begin{array}{l}\text { Developmental } \\
\text { stage }\end{array}$} & \multicolumn{4}{|c|}{ Estradiol-17 $\beta(3.5 \times \mathrm{M})$} \\
\hline & & 0 & $10^{-6}$ & $10^{-5}$ & $10^{-4}$ \\
\hline 0 & Eight-cell & $323(\%)$ & $218(\%)$ & $215(\%)$ & $209(\%)$ \\
\hline 1 & Morula & $310(96.0)^{a}$ & $210(96.3)^{a}$ & $206(95.8)^{a}$ & $200(95.7)^{a}$ \\
\hline 2 & Blastocyst & $301(93.2)^{a}$ & $205(94.0)^{\mathrm{a}}$ & $205(95.3)^{a}$ & $198(94.7)^{a}$ \\
\hline 3 & Hatched blastocyst & $61(18.9)^{a}$ & $44(20.2)^{a}$ & $55(25.6)^{b}$ & $54(25.8)^{b}$ \\
\hline 4 & Post-hatch stage 1 & $35(10.8)^{\mathrm{a}}$ & $24(11.0)^{a}$ & $40(18.6)^{b}$ & $37(17.7)^{b}$ \\
\hline 5 & Post-hatch stage 2 & $33(10.2)^{\mathrm{a}}$ & $23\left(10.6^{\mathrm{a}}\right.$ & $38(17.7)^{\mathrm{b}}$ & $32(15.3)^{\mathrm{b}}$ \\
\hline
\end{tabular}

$a, b$ differ significantly from each other $(p<0.05)$.

Table 3. Development of rat embryos in $\mathrm{m} 199 \mathrm{FCS}$ medium with addition of progesterone $\left(3.5 \times 10^{-6}, 10^{-5}, 10^{-4}\right)$ and estradiol-17 $\beta\left(3.5 \times 10^{-5} \mathrm{M}\right)$

\begin{tabular}{|c|c|c|c|c|c|}
\hline \multirow{2}{*}{$\begin{array}{l}\text { Day of } \\
\text { culture }\end{array}$} & \multirow{2}{*}{$\begin{array}{l}\text { Developmental } \\
\text { stage }\end{array}$} & \multicolumn{4}{|c|}{ Co-culture with progesterone $(3.5 \times \mathrm{M})$} \\
\hline & & 0 & $10^{-6}$ & $10^{-5}$ & $10^{-4}$ \\
\hline 0 & Eight-cell & $323(\%)$ & $209(\%)$ & $201(\%)$ & $213(\%)$ \\
\hline 1 & Morula & $310(96.0)^{a}$ & $202(96.7)^{a}$ & $201(100.0)^{a}$ & $210(98.6)^{a}$ \\
\hline 2 & Blastocyst & $303(93.8)^{a}$ & $196(93.8)^{a}$ & $194(96.5)^{a}$ & $203(95.3)^{a}$ \\
\hline 3 & Hatched blastocyst & $61(18.9)^{a}$ & $115(55.0)^{\mathrm{b}}$ & $131(65.2)^{c}$ & $124(58.2)^{b}$ \\
\hline 4 & Post-hatch stage 1 & $35(10.8)^{a}$ & $71(34.0)^{b}$ & $84(41.8) c$ & $64(30.0)^{\mathrm{b}}$ \\
\hline 5 & Post-hatch stage 2 & $33(10.2)^{a}$ & $61(29.2)^{b}$ & $79(39.3)^{c}$ & $61(28.6)^{b}$ \\
\hline
\end{tabular}

$a, b, c$ differ significantly from each other $(p<0.05)$.

Table 4. Development of rat embryos in conditioned medium with the addition of progesterone $\left(3.5 \times 10^{-6}, 10^{-5}, 10^{-4}\right)$ and estradiol-17 $\beta\left(3.5 \times 10^{-5} \mathrm{M}\right)$

\begin{tabular}{clcccc}
\hline \multirow{2}{*}{$\begin{array}{c}\text { Day of } \\
\text { culture }\end{array}$} & $\begin{array}{c}\text { Developmental } \\
\text { stage }\end{array}$ & \multicolumn{4}{c}{ Conditioned medium with progesterone $(3.5 \times \mathrm{M})$} \\
\cline { 4 - 6 } & \multicolumn{1}{c}{0} & \multicolumn{1}{c}{$10^{-6}$} & $10^{-5}$ & $10^{-4}$ \\
\hline 0 & Eight-cell & $218(\%)$ & $211(\%)$ & $204(\%)$ & $207(\%)$ \\
1 & Morula & $208(95.4)^{\mathrm{a}}$ & $202(95.7)^{\mathrm{a}}$ & $202(99.0)^{\mathrm{a}}$ & $197(95.2)^{\mathrm{a}}$ \\
2 & Blastocyst & $200(91.7)^{\mathrm{a}}$ & $195(92.4)^{\mathrm{b}}$ & $192(94.1)^{\mathrm{b}}$ & $194(93.7)^{\mathrm{b}}$ \\
3 & Hatched blastocyst & $36(16.5)^{\mathrm{a}}$ & $115(54.5)^{\mathrm{b}}$ & $129(63.2)^{\mathrm{b}}$ & $118(57.0)^{\mathrm{b}}$ \\
4 & Post-hatch stage 1 & $19(8.7)^{\mathrm{a}}$ & $67(31.8)^{\mathrm{b}}$ & $83(40.7)^{\mathrm{c}}$ & $61(29.5)^{\mathrm{b}}$ \\
5 & Post-hatch stage 2 & $19(8.7)^{\mathrm{a}}$ & $46(21.8)^{\mathrm{b}}$ & $78(38.2)^{\mathrm{c}}$ & $57(27.5)^{\mathrm{b}}$ \\
\hline
\end{tabular}

$a, b, c$ differ significantly from each other $(p<0.05)$. 
volved in achieving specialized UE cell roles is hormonally regulated. Delivery to and maintenance of such components at the appropriate site of function must be dependent on both hormone and epithelial cell polarity [21-23].

Blastocyst development remains the same in both $P_{4}$ and $E_{2}$, but hatching and post hatching increased with $\mathrm{P}_{4}$ although no direct comparison was made between them. It is also interesting that the combination of $P_{4}$ and $E_{2}$ is more effective. Little is known about the control of growth and differentiation of preimplantation embryos. Two distinct features during preimplantation embryo development are activation and cleavage of the embryo following fertilization and differentiation of embryonic cells into an inner cell mass and trophoectoderm at the blastocyst stage. In the mouse or rat, $\mathrm{P}_{4}$ and $\mathrm{E}_{2}$ are required for normal preimplantation embryo development in the reproductive tract $[24,25]$. Although fertilized embryos can develop into blastocysts within the reproductive tract of ovariectomized animals, a substantial loss in the number of embryos and a decrease in the number of cells per embryo occur. Treatment of these animals with an appropriate combination of $P_{4}$ and $E_{2}$ corrects these defects $[24,25]$. These observations suggest that while certain growth-promoting factors originating in the embryo are involved in autocrine regulation of embryo growth and differentiation, the full complement of preimplantation embryo development and differentiation requires additional paracrine factors that originate in the reproductive tract under the influence of $P_{4}$ and/or $E_{2}$. No direct effects of $P_{4}$ and/or $E_{2}$ on preimplantation embryo development have been documented.

Furthermore, blastocysts developed from 8-cell embryos cultured in groups, or singly in the presence of epidermal growth factor (EGF), showed a higher a incidence of zona-hatching compared with those cultured in the absence of EGF [26]. The detection of EGF receptors on the embryonic cell surface at the 8-cell/ morula and blastocyst stages supports our contention that EGF or TGF- $\alpha$ can influence preimplantation embryo development and blastocyst functions. The effects of EGF or TGFs are specific, since insulin-like growth factor-I (IGF-I) had no effect on embryo development [26].

The combination of $\mathrm{P}_{4}$ and $\mathrm{E}_{2}$ in more effective for hatching. It is possible to speculate that EGF production may be high in this condition. EGF has been linked with UE cell proliferation $[27,28]$. Estrogen behaves as a mitogen by inducing increases in EGF messenger RNA before the appearance of the functional receptor, which precedes DNA synthesis [27, 29]. Estrogen can increase the level of functional EGF in vivo [27, 30], promoting, via its specific tyrosine protein kinase cascade, the stimulation of transpiration and the synthesis of specific proteins involved in cell division. Julian et al. [31] reported that, in defined medium, which contained $E_{2}\left(2.5 \times 10^{-9 M}\right)$, UE cells that proliferated to confluence demonstrated separation of apical and basal plasma membrane domains and displayed preferential secretion of proteins and proteoglycans from the apical surface.

One of the major roles of $\mathrm{P}_{4}$ in the estrus cycle is to prepare the uterus for implantation. The implantation process is a complex interaction between embryonic and uterine cells and cell type-specific interactions between $P_{4}$ and $E_{2}$, but the monocular and cellular mechanisms involved in these $\mathrm{P}_{4}$ : $E_{2}$ regulated processes are not clearly understood. One emerging concept is that the $P_{4}$ : $E_{2}$ effect in the uterus and/or the embryos is transduced by growth factors, which function in an autocrine/paracrine manner.

\section{References}

1) Neider, G.L. and Macon, G.R. (1987): Uterine and oviductal protein secretion during early pregnancy in the mouse. J. Reprod. Fert., 81, 287-294.

2) Leese, H.J. (1988): The formation and function of oviduct fluid. J. Reprod. Fert., 82, 843-856.

3) Tsujii, H. (1998): Co-culture of rat ova with oviductal cells in m199FCS. J. Mamm. Ova Res., 15, 17-21.

4) Tantayaporn, P., Mallikarjuneswara, V.R., De-Carlo, S.J. and Clemetson, C.A.B. (1974): The effects of estrogen and $P$ on the volume and electrolyte content of the uterine luminal fluid of the rat. Endocrinology, 95, 1034-1045.

5) Surani, M.A.H. (1977): In: Development in Mammals, pp.245-305, Elsevier/Norzk Holland Biomedical Press, Amsterdam.

6) Anderson, T.L. and Hoffman, L.H. (1984): Alterations in epithelial glycocalyx of rabbit uteri during early pseudopregnancy and pregnancy and following ovariectomy. Am. J. Anat., 171, 321-334.

7) Hewilt, K., Beer, A.E. and Grinnell, F.(1979): Disappearance of anionic sites from the surface of the rat endometrial epithelium at the time of blastocyst implantation. Biol. Reprod., 21, 691-707.

8) Brinster, R.L. (1965): Studies on the development of mouse embryos in vitro. IV Interaction of energy sources. J. Reprod. Fert., 10, 227-240.

9) Roberts, R.M. and Bazer, F.W. (1988): The functions of uterine secretions. J. Reprod. Fert., 82, 875-892.

10) Parr, M.B. and Parr, E.L. (1985): Secretory immunoglobulin binding to bacteria in the mouse uterus af- 
ter mating. J. Reprod. Immunol., 8, 71-82.

11) Sherman, M.I. and Wudl, L.W. (1976): In: The Cell Surface in Animal Embryogenesis, pp. 81-125, Elsevier/North Holland, Amsterdam.

12) Psychoyos, A. (1986): Uterine receptivity for nidation. Ann. NY Acad. Sci., 476, 36-42.

13) Kimber, S.J. (1990): Glycoconjugates and cell surface interactions in pre- and peri-implantation mammalian embryonic development. Int. Rev. Cytol., 120, 53-167.

14) Moulton, B.C. and Koenig, B.B. (1986): Biochemical responses of luminal epithelium and uterine sensitization. Ann. NY Acad. Sci., 476, 95-109.

15) Lejeune, B. and Leroy, F. (1980): Role of uterine epithelium in inducing the decidual reaction. Prog. Reprod. Biol., 7, 92-101.

16) Glasser, S.R. (1990): Biochemical and structural changes in uterine endometrial cell types following natural or artificial deciduogenic stimuli. Troph. Res., 4, 377-416.

17) Psychoyos, A. (1973): Hormonal control of ovoimplantation. Vitam. Horm., 31, 201-256.

18) Meyers, K. (1970): Hormonal requirements for the maintenance of oestradiol-induced inhibition of uterine sensitivity in the ovariectomized rat. J. Endocrinol., 46, 431-436.

19) Glasser, S.R. and McCormack, S.A. (1980): In: The Endometrium, pp.173-192, Spectrum Publishing Co., New York.

20) Tachi, C., Tachi, S. and Lindner, H.R. (1972): Modification by progesterone of oestradiol induced cell proliferation, RNA synthesis and oestradiol distribution in the uterus. J. Reprod. Fert., 31, 59-76.

21) Simons, K. and Fuller, S.D. (1985): Cell Surface polarity in epithelia. Annu. Rev. Cell Biol., 1, 243-288.

22) Matlin, K.S. (1986): The sorting of proteins to the plasma membranes in epithelial cells. J. Cell Biol.,
103, 2565-2568.

23) Rodriguez-Boulan, E. and Nelson, W.J. (1989): Morphogenesis of the polarized epithelial cell phenotype. Science, 245, 718-725.

24) Roblero, L.S. and Garavagno, A.C. (1979): Effect of oestradiol-17 $\beta$ and progesterone on oviductal transport and early development of mouse embryos. J. Reprod. Fert., 57, 91-95.

25) Roblero, L. (1973): Effect of progesterone in vivo upon the rate of cleavage of mouse embryos. J. Reprod. Fert., 35, 153-155.

26) Vestweber, D., Gossler, A., Boller, K. and Kemler, R. (1987): Expression and distribution of cell adhesion molecule uvomorulin in mouse preimplantation embryos. Dev. Biol., 124, 451-456.

27) Lingham, R.B., Stancel, G.M. and Loose-Mithel, D.S. (1988): Estrogen regulation of epidermal growth factor receptor messenger ribonucleic acid. Mol. Endocrinology, 2, 230-235.

28) Mukku, V.R., Kirkland, J.L., Hardy, M. and Stancel, G.M. (1982): Hormonal control of uterine growth: temporal relationship between estrogen administration and deoxyribonucleic acid synthesis. Endocrinology, $11,480-487$.

29) DiAugustine, R.P., Petrusz, P., Bell, G.I., Brown, C.F., Korach, K.S., McLachlin, J.A. and Teng, C.T. (1988): Influence of estrogens on mouse uterine epidermal growth factor precursor protein and messenger ribonucleic acid. Endocrinology, 122, 2355-2363.

30) Clark, A.J.L., Richent, N., Merlino, G.T. and Pastan, I. (1985): Epidermal growth factor regulates the expression of its own receptor. Proc. Natl. Acad. Sci. USA, 82, 8374-8378.

31) Julian, J.A., Daniel, D.C. and Glasser, S.R. (1992): Polarized rat uterine epithelium in vitro: Responses to estrogen in defined medium. Endocrinology, 130, 68-78. 